\title{
New Data to the Knowledge on the Eriophyoid Fauna on Woody Plants in Hungary (Acari: Eriophyoidea)
}

\author{
G. GÓLYA, E. KOZMA and A. KOVÁCS \\ Szent István University, Faculty of Agriculture and Environmental Sciences, \\ Department of Plant Protection, H-2100 Gödöllö, P.O. Box 303, Hungary \\ Authors give a report on four eriophyoid species which were new for the Hungarian fauna \\ (Aculops berochensis Keifer and Delley; Aculops parakarensis Bagdasarian; Aculus ligustri Keifer; Aculus? \\ crataegumplicans Cotte). Three of them were found on new host-plants.
}

Keywords: Eriophyoid fauna, Aculops spp.

The eriophyoid mites are frequent on the cultivated and the adventitious plants, on monocotyledons and dicotyledons. Several researchers' work assisted to know the Hungarian fauna (Balás, 1939; Farkas, 1965, 1966; Dellei and Szendrey, 1989; Győrffy and Molnár, 1992; Ripka, 1997, Ripka and de Lillo, 1997). Farkas (1966) gave a key and general morphological characterization on the 249 species and the 20 subspecies which were found in Hungary until 1966. He described shortly the host-plants and the damages of these pests. Since then the number of the known eriophyoid mites increased considerably. Ripka (1997) observed further 27 new species for the Hungarian fauna and 63 new host-plants.

\section{Materials and Methods}

In 1999 many plant samples were taken from various cultivated and adventitious woody plants, from different parts of Hungary. Leaves and sprouts were collected randomly, from each side of the trees and the bushes. The occurrence of eriophyoid species were examined by stereomicroscope in laboratory. All the mites found were put in lactic acid. Lactic acid was used for cleaning, Keifer-II solution for staining of cuticula, and Keifer-III solution for preserving specimens. The identification of the genus was performed by using phase contrast microscope and the key of Boczek et al. (1989). The species were identified by using the catalogue of Davis et al. (1982) and Amrine and Stasny (1994) and on the basis of the original descriptions. 


\section{Results}

In 1999 four new species were found in the Hungarian eriophyoid fauna. Three of them appeared on new host-plants (Table 1).

Table 1

Eriophyoid mite species collected from woody plants

\begin{tabular}{llll}
\hline Species & Host-plant & Sampling place & Sampling date \\
\hline $\begin{array}{l}\text { Aculops berochensis } \\
\text { Keifer and Delley, 1971 }\end{array}$ & Prunus avium* & $\begin{array}{l}\text { Kiskunfélegyháza, } \\
\text { Bács-Kiskun county }\end{array}$ & 19.02 .1999 \\
$\begin{array}{l}\text { Aculops parakarensis } \\
\text { Bagdasarian, 1972 }\end{array}$ & Prunus spinosa* & Valkó, Pest county & 22.05 .1999 \\
$\begin{array}{l}\text { Aculus ligustri } \\
\text { (Keifer, 1938) }\end{array}$ & Ligustrum vulgare & Budapest & \\
$\begin{array}{l}\text { Aculus? crataegumplicans } \\
\text { (Cotte, 1910) }\end{array}$ & Crataegus monogyna* & Galgahévíz, Pest county & 09.06 .1999 \\
\hline
\end{tabular}

*new host-plants

\section{Discussion}

Aculops berochensis Keifer and Delley were found on Prunus avium in Hungary. Cherry was a new host-plant for this mite. Originally Keifer and Delley (1971) described Aculops berochensis on the undersurface of domestic plum (Prunus domestica) leaves in Canton of Neuchatel, in Switzerland. According to the catalogue of Amrine and Stasny (1994) this species occurs on Prunus armeniaca, Prunus cerasus, Prunus domestica, Prunus insititia, Prunus mahaleb, Prunus persica and Prunus spinosa. Castagnoli and Oldfield (1996) listed the following trees as host-plants of Aculops berochensis: apricot, mahaleb cherry, sour cherry, European plum, myrobalan plum, peach.

Aculops parakarensis Bagdasarian was collected from Prunus spinosa in Hungary. Blackthorn was a new host-plant for this mite. At first Bagdasarian (1972) described Aculops parakarensis on the undersurface of almond (Amygdalus communis) leaves in Armenia. Amrine and Stasny (1994) and Castagnoli and Oldfield (1996) mentioned the species on Amygdalus communis = Prunus dulcis, too. In Hungary Ripka (1997) and Ripka and de Lillo (1997) found Acalitus phloeocoptes Nalepa, Phyllocoptes abaenus Keifer, Diptacus gigantorhynchus Nalepa, and Rhinotergum schestovici Petanovic on Prunus spinosa, but they did not find Aculops parakarensis.

Aculus ligustri Keifer was collected on the well-known host-plant of the species, namely on Ligustrum vulgare, in Budapest. In 1938 Keifer described this mite and named Phyllocoptes ligustri on the above-mentioned plant in California. Later Keifer (1959) changed the name of Phyllocoptes to Aculus. Ripka (1997) and Ripka and de Lillo (1997) observed Shevtchenkella ligustri Farkas on Ligustrum vulgare and Aceria ligustri Keifer 
on the leaves of Ligustrum ovalifolium, but did not collect Aculus ligustri in Hungary. According to the catalogue of Amrine and Stasny (1994) Aculus ligustri can be found on both plants.

Aculus? crataegumplicans Cotte appeared in Hungary as a new species for the Hungarian eriophyoid fauna on Crataegus monogyna which was a new host-plant. The species was described by Cotte (1910) on the leaves of Crataegus oxyacanthoides and was named Eriophyes crataegumplicans. On the basis of Amrine and Stasny (1994) Aculus? crataegumplicans occurred on Crataegus oxyacanthoides and Crataegus laevigata. However, according to Simon (1992) these plants are the same.

\section{Literature}

Amrine, J. W. Jr. and Stasny, T. A. (1994): Catalog of the Eriophyoidea (Acarina: Prostigmata). Indira Publishing House, West Bloomfield, Michigan, $531 \mathrm{pp.}$

Bagdasarian, A. T. (1972): Dva novych vida eriofiodnych klescej na mindale v Armenii (Acariformes, Eriophyoidea) (Two new eriophyoid mite species on almond in Armenia). Dokl. A. N. Arm. SSR 14,188-192.

Balás, G. (1939): Levélatka okozta növénybetegségek Magyarországon (Plant diseases caused by gall mites in Hungary). Magyar Királyi Kertészeti Tanintézet Közleménye 5, 52-70.

Boczek, J. H., Shevtchenko, V. G. and Davis, R. (1989): Generic key to world fauna of eriophyid mites (Acarida: Eriophyoidea). Warsaw Agricultural University Press, Warsaw, $191 \mathrm{pp}$.

Castagnoli, M. and Oldfield, G. N. (1996): Other fruit trees and nut trees. In: Lindquist, E. E., Sabelis, M. W. and Bruin, J. (eds): Eriophyoid Mites, Their Biology, Natural Enemies and Control. Elsevier, Amsterdam, World Crop Pests 6, 543-559.

Cotte, J. (1910): Nouvelle acarocecidie de Crataegus oxyacanthoides Thuill. Comptes Rendus Hebdomadaires, Societe de Biologie, Marseille, 68, 643-645.

Davis, R., Flechtmann, C. H. W., Boczek, J. H. and Barké, H. E. (1982): Catalogue of Eriophyoid Mites (Acari: Eriophyoidea). Warsaw Agricultural University Press, Warsaw, 254 pp.

Dellei, A. and Szendrey, L. (1989): Fitofág és ragadozó atkafajok előfordulása Heves megye gyümölcsöseiben (Occurrence of herbivorous and predatory mite species in the orchards of Heves county). Növényvédelem 25, 437-442.

Farkas, H. (1965): Spinnentiere, Eriophyidae (Gallmilben). In: Die Tierwelt Mitteleuropas, Band 3, Lief 3, Verlag von Quelle and Meyer, Leipzig, $155 \mathrm{pp}$.

Farkas, H. (1966): Gubacsatkák (Gall mites) - Eriophyidae. In: Magyarország állatvilága (Fauna Hungariae) 15, Akadémiai Kiadó, Budapest, 164 pp.

Győrffy Molnár, J. (1992): Új levélatkafaj a hazai faunában (New eriophyoid species in the Hungarian fauna). Növényvédelem 28, 320-322.

Keifer, H. H. (1938): Eriophyoid Studies I. The Bulletin Department of Agriculture State of California 27, 181-206.

Keifer, H. H. (1959): Eriophyoid Studies XXVII. Occasional Paper, California Department of Agriculture, 18 pp.

Keifer, H. H. and Delley, B. (1971): Description of a new species of Aculops Keifer (Arachn., Acar.) noxious on plum trees in Switzerland. Mitteilungen der Schweizerischen Entomologischen Gesellschaft, Bulletin de la Societe Entomologique Suisse, Band 44, 342-344.

Ripka, G. (1997): A díszfák és díszcserjék levéltetü- és atkafaunája (Aphid and mite fauna of ornamental trees and shrubs). PhD. Dissertation. Kertészeti és Élelmiszeripari Egyetem, Budapest, iv + 209 pp.

Ripka, G. and de Lillo, E. (1997): New data to the knowledge on the eriophyoid fauna in Hungary (Acari: Eriophyoidea). Folia Entomologica Hungarica 28, 147-157.

Simon, T. (1992): A magyarországi edényes flóra határozója, Harasztok - virágos növények (Key to the Hungarian flora. Ferns - flowery plants). Tankönyvkiadó, Budapest, 892 pp. 